\title{
Plasmalemmal Phosphatidylinositol-4,5-Bisphosphate Level Regulates the Releasable Vesicle Pool Size in Chromaffin Cells
}

\author{
Ira Milosevic, ${ }^{1,2}$ Jakob B. Sørensen, ${ }^{1}$ Thorsten Lang, ${ }^{2}$ Michael Krauss, ${ }^{3}$ Gábor Nagy, ${ }^{1}$ Volker Haucke, ${ }^{3}$ Reinhard Jahn, ${ }^{2}$ \\ and Erwin Neher ${ }^{1}$ \\ Departments of ${ }^{1}$ Membrane Biophysics and ${ }^{2}$ Neurobiology, Max Planck Institute for Biophysical Chemistry, D-37077 Göttingen, Germany, and ${ }^{3}$ Institute of \\ Chemistry-Biochemistry, Freie Universität Berlin, D-14195 Berlin, Germany
}

\begin{abstract}
During exocytosis, certain phospholipids may act as regulators of secretion. Here, we used several independent approaches to perturb the phosphatidylinositol-4,5-bisphosphate $\left[\mathrm{PI}(4,5) \mathrm{P}_{2}\right]$ level in bovine chromaffin cells to investigate how changes of plasmalemmal $\mathrm{PI}(4,5) \mathrm{P}_{2}$ affect secretion. Membrane levels of $\mathrm{PI}(4,5) \mathrm{P}_{2}$ were estimated by analyzing images of lawns of plasma membranes labeled with fluorescent probes specific for $\mathrm{PI}(4,5) \mathrm{P}_{2}$. The specific $\mathrm{PI}(4,5) \mathrm{P}_{2}$ signal was enriched in submicrometer-sized clusters. In parallel patch-clamp experiments on intact cells, we measured the secretion of catecholamines. Overexpression of phosphatidylinositol-4-phosphate-5-kinase I $\gamma$, or infusion of $\mathrm{PI}(4,5) \mathrm{P}_{2}$ through the patch pipette, increased the $\mathrm{PI}(4,5) \mathrm{P}_{2}$ level in the plasma membrane and potentiated secretion. Expression of a membrane-targeted inositol 5-phosphatase domain of synaptojanin 1 eliminated $\mathrm{PI}(4,5) \mathrm{P}_{2}$ from the membrane and abolished secretion. An inhibitor of phosphatidylinositol-3 kinase, 2-(4-morpholinyl)-8-phenyl-4H-1-benzopyran-4-one, led to a transient increase in the $\mathrm{PI}(4,5) \mathrm{P}_{2}$ level that was associated with a potentiation of secretion. After prolonged incubation, the level of $\mathrm{PI}(4,5) \mathrm{P}_{2}$ decreased and secretion was inhibited. Kinetic analysis showed that changes in $\mathrm{PI}(4,5) \mathrm{P}_{2}$ levels led to correlated changes in the size of two releasable vesicle pools, whereas their fusion kinetics remained unaffected. We conclude that during both short- and long-term manipulations of $\mathrm{PI}(4,5) \mathrm{P}_{2}$ level secretion scales with plasma membrane $\mathrm{PI}(4,5) \mathrm{P}_{2}$ content and that $\mathrm{PI}(4,5) \mathrm{P}_{2}$ has an early effect on secretion by regulating the number of vesicles ready for release.
\end{abstract}

Key words: exocytosis; phosphatidylinositol-4,5-bisphospate; chromaffin cell; phosphatidylinositol 4-phosphate 5-kinase; plasmalemmal microdomains; LY294002

\section{Introduction}

Neuroendocrine exocytosis is a highly regulated process comprising translocation of secretory vesicles to the plasma membrane (docking), the formation of an exocytotic machinery between vesicles and membrane (priming), and, finally, fusion resulting in the release of the vesicular contents into the extracellular space. The fusion of large dense-core vesicles (LDCVs) in chromaffin cells is often used to study the basic concepts of exocytosis (Rettig and Neher, 2002).

In chromaffin cells, it was found that an ATP-dependent priming step precedes the ATP-independent $\mathrm{Ca}^{2+}$-triggered fusion step (Holz et al., 1989). Additional experiments revealed that the presence of phosphatidylinositides, but not of phospholipase

\footnotetext{
Received Sept. 10, 2004; revised Jan. 24, 2005; accepted Jan. 24, 2005.

This work was supported by grants from the Deutsche Forschungsgemeinschaft (SFB 523/TP B4 to E.N., SPP 1128 and SFB 406/TP B8 to T.L. and R.J., SFB 523/TP B8 and SFB 366/TP B11 to V.H.), INTAS (01-2095 to E.N.), and the Fonds der Chemischen Industrie (to V.H.). V.H. is a European Molecular Biology Organization Young Investigator. I.M. is a PhD student of the International MD-PhD/PhD Program in the Neurosciences of the International Max Planck Research School and holds a Boehringer-Ingelheim Fond Fellowship. We thank Ina Herfort and Dirk Reuter for expert technical assistance and Dr. Ralf B. Nehring for cloning consulting.

Correspondence should be addressed to Dr. Sørensen at the above address. E-mail: jsoeren@gwdg.de.

DOI:10.1523/JNEUROSCI.3761-04.2005

Copyright $\odot 2005$ Society for Neuroscience $\quad$ 0270-6474/05/252557-09\$15.00/0
}

$\mathrm{C}$ cleavage products, is necessary for $\mathrm{Ca}^{2+}$-dependent exocytosis in chromaffin cells (Eberhard et al., 1990). A screening of cytoplasmic factors required for ATP-dependent priming in PC12 cells identified two enzymes involved in phosphoinositide metabolism: phosphatidylinositol transfer protein (PITP $\alpha$ ) (Hay and Martin, 1993) and phosphatidylinositol 4-phosphate 5-kinase (PI4P5K) (Hay et al., 1995). Because PI4P5K uses ATP to synthesize phosphatidylinositol-4,5-bisphospate $\left[\mathrm{PI}(4,5) \mathrm{P}_{2}\right]$, a role for $\mathrm{PI}(4,5) \mathrm{P}_{2}$ in exocytosis was hypothesized (Hay et al., 1995; Martin et al., 1997). Later, it was found that the overexpressed pleckstrin homology domain of phospholipase C- $\delta_{1}$ (PH-PLC $\delta_{1}$ ), which specifically binds $\mathrm{PI}(4,5) \mathrm{P}_{2}$, localized to the plasma membrane and inhibited $\mathrm{Ca}^{2+}$-dependent exocytosis (Holz et al., 2000). Olsen et al. (2003) used capacitance measurements in pancreatic $\beta$-cells and showed that infusion of phosphatidylinositol 4-phosphate $[\mathrm{PI}(4) \mathrm{P}]$ or $\mathrm{PI}(4,5) \mathrm{P}_{2}$ increased the size of the readily releasable pool (RRP) of vesicles. Recently, Aikawa and Martin (2003) demonstrated that overexpression of a constitutively active ARF6 mutant caused redistribution of $\mathrm{PI}(4,5) \mathrm{P}_{2}$ and PI4P5KI $\gamma$ from plasma membrane to endosomal membranes and inhibited LDCV secretion.

The above studies indicate that $\mathrm{PI}(4,5) \mathrm{P}_{2}$ is intimately involved in exocytosis of LDCVs. One idea is that $\mathrm{PI}(4,5) \mathrm{P}_{2}$ recruits 
proteins to the plasma membrane and thereby acts as a nucleation center for an exocytosis apparatus (Hay et al., 1995), in line with a relatively early role in exocytosis. On the other hand, a recent in vitro study showed that binding of synaptotagmin 1, the $\mathrm{Ca}^{2+}$ sensor for exocytosis, to $\mathrm{PI}(4,5) \mathrm{P}_{2}$-containing membranes via its $\mathrm{C} 2 \mathrm{~B}$ domain increased the speed of insertion of synaptotagmin 1 side chains into that membrane after the addition of $\mathrm{Ca}^{2+}$ (Bai et al., 2004). It was suggested that changes in the $\mathrm{PI}(4,5) \mathrm{P}_{2}$ level could regulate release rates, which would imply $\mathrm{PI}(4,5) \mathrm{P}_{2}$ in regulating the last $\mathrm{Ca}^{2+}$-dependent step in exocytosis. Thus, it remains to be established where exactly in the exocytosis pathway $\mathrm{PI}(4,5) \mathrm{P}_{2}$ is required.

We have used several independent approaches to upregulate and downregulate $\mathrm{PI}(4,5) \mathrm{P}_{2}$ levels in bovine chromaffin cells (BCCs). The effects of these manipulations were assessed semiquantitatively by detection of $\mathrm{PI}(4,5) \mathrm{P}_{2}$ in isolated plasma membrane lawns by exogeneous green fluorescent protein (GFP)tagged PH domain. In parallel experiments, exocytosis of LDCVs was monitored by patch-clamp capacitance measurements and amperometry. We discovered that the size of the releasable vesicle pools, but not their release kinetics, scales with the amount of $\mathrm{PI}(4,5) \mathrm{P}_{2}$ in the plasma membrane, no matter whether $\mathrm{PI}(4,5) \mathrm{P}_{2}$ is regulated acutely or chronically, suggesting that $\mathrm{PI}(4,5) \mathrm{P}_{2}$ is a key physiological regulator of chromaffin cell secretion.

\section{Materials and Methods}

Antibodies, expression constructs, and virus generation. Mouse monoclonal antibody was used to detect $\mathrm{PI}(4,5) \mathrm{P}_{2}$ (Assay Design, Ann Arbor, $\mathrm{MI}$ ), and the primary antibody was visualized using cyanine 5 (Cy5)conjugated goat anti-mouse secondary antibody (Jackson ImmunoResearch, West Grove, PA). Unless indicated otherwise, the chemicals used were purchased from Sigma (Taufkirchen, Germany).

For protein expression, pET28a-His ${ }_{6}$-GFP-PH-PLC $\delta_{1}$ was generated by subcloning the fusion construct between the $\mathrm{PH}$ domain from PLC $\delta_{1}$ and enhanced GFP (EGFP) (attached to the C-terminal end of the PH domain) into pET28a. The triple mutation K30A, K32A, W36N of GFPPH-PLC $\delta_{1}$, which does not bind to PI $(4,5) \mathrm{P}_{2}$, was generated by PCR and also cloned into pET28a. For the construction of a vector encoding the proteins tagged with monomeric red fluorescent protein (mRFP) at their $\mathrm{N}$ terminus, mRFP containing an initiator, ATG, but no stop codon was amplified from pmRFP (a gift from Dr. H.-D. Söling, Göttingen, Germany) and inserted into the mammalian expression vector pcDNA3 (Invitrogen, San Diego, CA) yielding pcmRFP. The coding sequences for PI4P5KI $\gamma$ and the membrane-tagged 5-inositol phosphatase domain of synaptojanin 1 (IPP1-CAAX) (Krauss et al., 2003) were inserted into pcmRFP. For infection of BCCs, the viral constructs pSFV1-PI4P5KI $\gamma$ IRES-GFP and pSFV1-IPP1-CAAX-IRES-GFP were generated: a viral pSFV1 vector (Invitrogen) was modified by the introduction of an internal ribosome entry site from poliovirus and EGFP. PI4P5KI $\gamma$ was cut from pGFP-C1-PI4P5KI $\gamma$ (Krauss et al., 2003) and subcloned into the modified pSFV1 using the PmeI site. IPP1-CAAX was cut from pcDNAIPP1-CAAX (Krauss et al., 2003) and cloned into the modified pSFV1 using the BamHI/PmeI sites. The sequences of all constructs were verified by DNA sequencing. Virus production was performed as described previously (Ashery et al., 1999).

Expression and purification of wild-type and mutated GFP-PH-PLC $\delta_{1}$. Escherichia coli BL21 (DE3) cells transformed with wild-type (wt) or mutated pET28a-His 6 -GFP-PH-PLC $\delta_{1}$ were grown in Luria broth medium containing $50 \mu \mathrm{g} / \mathrm{ml}$ kanamycin at $37^{\circ} \mathrm{C}$ to an $\mathrm{OD}_{600}$ of 0.8 . Protein expression was induced by the addition of $0.5 \mathrm{~mm}$ isopropyl-1-thio- $\beta$-Dgalactopyranoside for $4 \mathrm{~h}$. The cell pellet was resuspended in $35 \mathrm{ml}$ of ice-cold PBS containing $1 \mathrm{~mm}$ phenylmethylsulfonyl fluoride and incubated with lysozyme for $10 \mathrm{~min}$ on ice. After sonification, $1 \%$ Triton X-100 and 1\% 3-[(3-cholamidopropyl)dimethylammonio]-1-propanesulfonate were added. The mixture was incubated for another $10 \mathrm{~min}$ and then centrifuged at $25,000 \times g$ for $15 \mathrm{~min}$. The supernatant was supple- mented with $20 \mathrm{~mm}$ imidazol and incubated with nickel-nitrilotriacetic acid-agarose (Qiagen, Hilden, Germany) for $2 \mathrm{~h}$ at $4^{\circ} \mathrm{C}$. The collected beads were washed twice with PBS buffer containing $20 \mathrm{~mm}$ imidazol, once with PBS buffer containing $40 \mathrm{~mm}$ imidazol, and once with K-Glu buffer (in mM: 120 potassium glutamate, 20 potassium acetate, 20 HEPES, and $4 \mathrm{MgCl}_{2}, \mathrm{pH}$ 7.2). The beads were subsequently resuspended in $2 \mathrm{ml}$ of K-Glu buffer supplemented with $10 \mathrm{~mm}$ EDTA, and after 30 min, thrombin (30 U; Sigma) was added and incubated for at least $4 \mathrm{~h}$. The supernatant containing $\mathrm{His}_{6}$-tag-cleaved protein was dialyzed twice against $0.5 \mathrm{~L} \mathrm{~K}$-Glu buffer supplemented with $1 \mathrm{~mm}$ dithiothreitol. Finally, the dialyzed solution was sedimented in a microcentrifuge $(14,000$ rpm for $30 \mathrm{~min}$ at $4^{\circ} \mathrm{C}$ ), and the protein concentration of the supernatant was determined by the method of Bradford. The protein was analyzed by SDS-PAGE and Coomassie staining. Two bands were detected: one of the appropriate size ( $\sim 75 \%$ of the total protein amount) and another significantly smaller. Only the bigger band associated specifically with $\mathrm{PI}(4,5) \mathrm{P}_{2}$ liposomes.

Liposome binding with wt and triple mutated GFP-PH-PLC $\delta_{1}$. Liposomes containing $70 \%$ phosphatidylcholine, $20 \%$ phosphatidylethanolamine, and $10 \% \mathrm{PI}$ or $10 \% \mathrm{PI}(4,5) \mathrm{P}_{2}$ were prepared as described previously (Rohde et al., 2002). Fifty microliters of each liposome suspension $(100 \mu \mathrm{g})$ were incubated in cytoplasmic buffer (in mM: 25 HEPES, pH $7.2,25 \mathrm{KCl}, 2.5$ magnesium acetate, and 150 potassium glutamate) with 3 $\mu \mathrm{g}$ of wt or mutated GFP-PH-PLC $\delta_{1}$ for $15 \mathrm{~min}$ at room temperature in a final volume of $100 \mu \mathrm{l}$. The mixture was centrifuged at $35,000 \times g$ for $1 \mathrm{~h}$ at $4^{\circ} \mathrm{C}$. The pellet was resuspended in Laemmli sample buffer.

Cell culture and transfection. The primary culture of BCCs was prepared as described previously (Nagy et al., 2002). The neuroendocrine cell line PC12 (clone 251) was maintained and propagated as described previously (Lang et al., 1997). Viral infection was performed on cultured BCCs $12-36 \mathrm{~h}$ after plating. Transfection of PC12 cells with wt and mutated GFP-PH-PLC $\delta_{1}$, mRFP-PI4P5KI $\gamma$, and mRFP-IPP1-CAAX was performed as described previously (Lang et al., 1997).

Electrophysiological and electrochemical measurements. Whole-cell patch-clamp capacitance, amperometry, flash photolysis of caged calcium, and intracellular $\mathrm{Ca}^{2+}$ measurements were performed as described previously (Nagy et al., 2002). PI(4,5) $\mathrm{P}_{2}$ isolated from bovine spinal cord was obtained from Calbiochem (Darmstadt, Germany) and dissolved in the pipette-filling solution by sonification for $15 \mathrm{~min}$ on ice. During the recordings, the BCCs were maintained in extracellular solution (145 mM NaCl, $2.8 \mathrm{~mm} \mathrm{KCl}, 2 \mathrm{~mm} \mathrm{CaCl}_{2}, 1 \mathrm{~mm} \mathrm{MgCl}_{2}, 10 \mathrm{~mm}$ HEPES, and $2 \mathrm{mg} / \mathrm{ml} \mathrm{D}$-glucose, $\mathrm{pH} 7.20,305 \mathrm{mOsm} / \mathrm{kg})$. In the experiments with short-term 2-(4-morpholinyl)-8-phenyl-4H-1-benzopyran4-one (LY294002) application, a local perfusion system was used. Kinetic analysis was performed fitting individual capacitance traces with a tripleexponential function as described previously (Nagy et al., 2004). The amplitudes and time constants of the two faster exponentials define the size and release kinetics of the slowly releasable pool (SRP) and the RRP, respectively, whereas the slowest exponential was included to correct for the sustained component of release. Because the time constant of the sustained component is too slow to be measured accurately in this way, this third exponential was not used directly. Instead, we subtracted the amplitudes of the fast and slow burst from the total amount of secretion during $5 \mathrm{~s}$ and calculated the linear rate of sustained release. Statistical testing of amplitudes and time constants of the kinetics components was performed by the nonparametric Mann-Whitney $U$ test. Each experimental condition has been compared with control cells obtained from the same cell preparations. The values given represent the mean \pm SEM.

Generation of plasma membrane sheets from BCCs and PC12 cells. BCCs were plated on $25 \mathrm{~mm}$ glass coverslips that had been pretreated with a 0.1 $\mathrm{mg} / \mathrm{ml}$ poly-L-lysine (Sigma) for $30 \mathrm{~min}\left(5 \times 10^{5}\right.$ to $7 \times 10^{5}$ cells/ coverslip) and kept at $37^{\circ} \mathrm{C}$ in $8 \% \mathrm{CO}_{2}$. Cells were used for experiments 24-36 h after plating. For chromaffin cells, membrane sheets were made by placing the coverslip into $150 \mathrm{ml}$ of ice-cold sonication buffer $(120 \mathrm{mM}$ potassium glutamate, $20 \mathrm{~mm}$ potassium acetate, $20 \mathrm{~mm}$ HEPES, $2 \mathrm{~mm}$ ATP, $100 \mu \mathrm{M}$ GTP, $4 \mathrm{~mm} \mathrm{MgCl}_{2}$, 4 mм EGTA, 6 mm Ca-EGTA, and 300 $\mathrm{nm}\left[\mathrm{Ca}^{2+}\right]_{\text {free }}$ pH 7.2, $310 \mathrm{mOsm} / \mathrm{kg}$; bubbled with $\mathrm{N}_{2}$ for $30 \mathrm{~min}$ ) in a round glass beaker with a final volume of $300 \mathrm{ml}$. A coverslip with attached cells was centered $12 \mathrm{~mm}$ under the sonication tip $(2.5 \mathrm{~mm})$, and 
the cells were disrupted applying a single ultrasound pulse (Sonifier 450, power setting at 1.8 and a duty cycle of $100 \mathrm{~ms}$; Branson Ultrasonics, Danbury, CT). Apart from chromaffin cells, the primary culture contained a low number of other cell types, mainly endothelial cells and erythrocytes. However, the membrane sheets generated from these cells differed in their size and level of staining for syntaxin 1 , so that they were easily recognized and excluded from analysis. Membrane sheets from PC12 cells were generated as described previously (Avery et al., 2000).

Fluorescence on plasma membrane sheets generated from BCCs and PC12 cells. In experiments with recombinant GFP-PH-PLC $\delta_{1}$, freshly prepared membrane sheets from BCCs or PC12 cells were incubated for 10 or 15 min with $3 \mu \mathrm{M}$ GFP-PH-PLC $\delta_{1}$ in K-Glu buffer with $3 \%$ BSA. Subsequently, the sheets were washed for $100 \mathrm{~s}$ in K-Glu buffer and fixed for at least $2 \mathrm{~h}$ in $4 \%$ paraformaldehyde in PBS at room temperature. For visualizing the plasma membrane, 1-(4-trimethyl-amoniumphenyl)-6phenyl-1,3,5-hexatriene (TMA-DPH) or 1,1'-dihexadecyl-3,3,3',3'tetramethylindocarbocyanine perchlorate $\left(\right.$ DiIC $\left._{16}\right)$ (Molecular Probes, Eugene, OR) were used. Immunofluorescence on PC12 membrane sheets was performed as described previously (Lang et al., 2001).

All samples were examined with an Axiovert 100 TV fluorescence microscope (Zeiss, Oberkochen, Germany) with a $100 \times, 1.4$ numerical aperture plan achromate objective using the appropriate fluorescence filters (excitation filter G 365, BS 395 and emission filter LP 420 were used for TMA-DPH dye; excitation filter BP 480/40, BS 505 and emission filter BP 527/30 were used for GFP; excitation filter BP 590/60, BS 660 and emission filter BP 662/76 were used for Cy5 dye). Throughout all experiments, the focal position of the objective was controlled using a lowvoltage piezo translater driver and a linear variable transformer displacement controller (Physik Instrumente, Waldbronn, Germany). The images were taken with a back-illuminated frame transfer CCD camera (2x512x512-EEV chip, $13 \times 13 \mu \mathrm{m}$ pixel size; Princeton Instruments, Trenton, NJ) with a magnifying lens $(1.6 \times$ or $2.5 \times$ Optovar $)$ to avoid spatial undersampling by the larger pixels. Digital image analysis was performed using MetaMorph software (Universal Imaging, West Chester, PA). The size of $\mathrm{PI}(4,5) \mathrm{P}_{2}$ clusters was estimated by fitting onedimensional Gaussians to a line-scan profile through the center of selected fluorescent spots as described previously (Lang et al., 2001). The point-spread function was identified by fitting two-dimensional Gaussian functions to the fluorescence intensity profile of $220 \mathrm{~nm}$ beads (TetraSpeck microfluorospheres; Molecular Probes) and was determined to be $246 \mathrm{~nm}$. To perform comparative quantitation of fluorescence intensity, plasma membrane sheets were identified in the TMA-DPH images. A $3.3 \times 3.3 \mu \mathrm{m}(40 \times 40$ pixels; 1 pixel corresponding to $81.25 \mathrm{~nm})$ region of interest was defined on the randomly selected membrane and transferred to the other channels. The fluorescence intensity was quantified by measuring the average intensity of the area. The local background was measured in the area outside the membrane sheets and subtracted. For each condition, at least 30 membrane sheets were analyzed in each experiment. Intensity values are given as mean \pm SEM. Images for display are presented on a linear intensity scale, usually scaled between the minimal and maximal value present in the region of interest. In some cases, the maximal value was decreased, resulting in local image saturation, to make finer structures (microdomains) visible.

\section{Results}

A spatially resolved assay for $\mathrm{PI}(4,5) \mathrm{P}_{2}$ in the plasma membrane of chromaffin and PC12 cells

We aimed at comparing the amount of $\mathrm{PI}(4,5) \mathrm{P}_{2}$ in the plasma membrane with LDCV secretion from chromaffin cells as measured electrophysiologically. To measure $\mathrm{PI}(4,5) \mathrm{P}_{2}$ levels in the plasma membrane, we adapted a microscopic assay that has recently been developed for PC12 cells and fibroblasts to measure the amount and spatial distribution of plasma membrane constituents (Lang et al., 2001, 2002). Cells grown on coverslips are disrupted by a brief ultrasonic pulse, leaving behind lawns of plasma membrane with the cytosolic face being directly accessible to external probes. In addition, some intact cells are usually still present. To visualize $\mathrm{PI}(4,5) \mathrm{P}_{2}$, we incubated membrane sheets prepared from PC12 cells with exogenously added $\mathrm{PI}(4,5) \mathrm{P}_{2}-$ binding PH domain of PLC $\delta_{1}$ fused to GFP (GFP-PH-PLC $\delta_{1}$ ) that was previously shown to bind selectively to $\mathrm{PI}(4,5) \mathrm{P}_{2}$ (Stauffer et al., 1998; Várnai and Balla, 1998). We observed strong labeling of membrane sheets (Fig. $1 \mathrm{~B}$ ), whereas intact cells were not labeled (data not shown), in agreement with the general finding that $\mathrm{PI}(4,5) \mathrm{P}_{2}$ is only present in the inner plasma membrane leaflet. The labeling exhibited a punctate staining pattern distributed over the entire plasma membrane. To confirm the integrity of the membrane sheets, the sheets were visualized using TMADPH, a lipophilic styryl dye (Fig. $1 A$ ). Punctate labeling by GFPPH-PLC $\delta_{1}$ was detected in areas where the TMA-DPH membrane staining was uniform (Fig. $1 C, D$ ), revealing that it was not attributable to local increases in the membrane area (e.g., attributable to infoldings). Similar results were obtained when the lipid dye DiIC $_{16}$ instead of TMA-DPH was used (data not shown).

Several experiments were performed to ensure that GFP-PHPLC $\delta_{1}$ labeling of the membrane sheets can be used to detect $\mathrm{PI}(4,5) \mathrm{P}_{2}$. First, we constructed a triple mutant of GFP-PH$\mathrm{PLC} \delta_{1}$ deficient in $\mathrm{PI}(4,5) \mathrm{P}_{2}$ binding (K30A, K32A, W36N GFPPH-PLC $\delta_{1}$ ). In contrast to the wt GFP-PH-PLC $\delta_{1}$, this mutant did not bind $\mathrm{PI}(4,5) \mathrm{P}_{2}$ liposomes (Fig. 1E,F). When applied to membrane sheets, no labeling by the triple mutant was observed $(<0.3 \%$ of the wt signal) (Fig. 1G,H). Next, we compared labeling with a $\mathrm{PI}(4,5) \mathrm{P}_{2}$-specific antibody to GFP-PH-PLC $\delta_{1}$ staining. When applied to the same membrane sheets simultaneously, the two $\mathrm{PI}(4,5) \mathrm{P}_{2}$ ligands showed similar staining patterns (Fig. $1 I, K)$, which partly overlapped. Finally, we tested whether binding of GFP-PH-PLC $\delta_{1}$ competes with antibody binding. When PC12 cell membrane sheets were incubated with a mixture of anti-PI $(4,5) \mathrm{P}_{2}$ antibody and increasing amounts of GFP-PHPLC $\delta_{1}$, a gradual decrease of anti-PI $(4,5) \mathrm{P}_{2}$ antibody labeling was observed (Fig. $1 \mathrm{~L}$ ). Hence, we conclude that GFP-PH-PLC $\delta_{1}$ is a reliable reporter of plasmalemmal $\mathrm{PI}(4,5) \mathrm{P}_{2}$. An alternative reporter would be the anti-PI $(4,5) \mathrm{P}_{2}$ antibody, but to avoid probemediated $\mathrm{PI}(4,5) \mathrm{P}_{2}$ clustering or coalescence of clusters, we preferred to used GFP-PH-PLC $\delta_{1}$, which binds $\mathrm{PI}(4,5) \mathrm{P}_{2}$ with a oneto-one stochiometry.

GFP-PH-PLC $\delta_{1}$ labeling was very stable in membrane sheets: the level of fluorescent probe remained unchanged for at least 30 min after staining, also in experiments in which membrane sheets were not fixed after the addition of GFP-PH-PLC $\delta_{1}$. We estimated the size of the clusters by fitting Gaussians to a line-scan profile through the center of selected fluorescent puncta (Lang et al., 2001). That method gave a size of $306 \pm 13 \mathrm{~nm}$ after correction for point-spread function ( $n=60$ puncta). The clustering of the GFP-PH-PLC $\delta_{1}$ signal was disrupted when cholesterol was extracted from the membrane using methyl- $\beta$-cyclodextrin (data not shown). Clustering was evident in most experiments, but uniform GFP-PH-PLC $\delta_{1}$ staining was observed in some cells, particularly on sheets with very intense TMA-DPH staining.

In the above, we used the easily accessible PC12 cells and the previously published method for membrane sheet generation to define the basal properties of the $\mathrm{PI}(4,5) \mathrm{P}_{2}$ assay. However, for electrophysiological experiments, we preferred to use chromaffin cells, because chromaffin cells, in contrast to PC12 cells, display fast secretion of LDCVs on the millisecond time scale as detected electrophysiologically. This property allows us to address the question at which step $\mathrm{PI}(4,5) \mathrm{P}_{2}$ acts in the secretory cascade. We therefore developed a membrane sheet assay for chromaffin cells by enhancing cell attachment by poly-L-lysine coating of the glass coverslips and modifying the sonication procedure (see Materials and Methods). When membrane sheets from chromaffin cells 
were incubated with GFP-PH-PLC $\delta_{1}$, we again observed a punctate distribution of $\mathrm{PI}(4,5) \mathrm{P}_{2}$ in the membrane (see Fig. $5 C$ ). The specificity of the GFP-PH-PLC $\delta_{1}$ signal in chromaffin cells was verified by repeating the experiments in Figure 1, G and $H$, which gave indistinguishable results. The estimated size of $\mathrm{PI}(4,5) \mathrm{P}_{2}$ clusters in BCCs was comparable with the one calculated in PC12 cells $(319 \pm 12 \mathrm{~nm} ; n=50$ puncta). Indeed, in every aspect tested, we obtained similar results with the $\mathrm{PI}(4,5) \mathrm{P}_{2}$ assay in PC12 cells and chromaffin cells.

We conclude that $\mathrm{PI}(4,5) \mathrm{P}_{2}$ can be specifically detected in isolated membrane sheets by the addition of exogeneous GFP$\mathrm{PH}-\mathrm{PLC} \delta_{1}$. Hence, we used this method to semiquantitatively evaluate the effect of manipulations on plasma membrane $\mathrm{PI}(4,5) \mathrm{P}_{2}$ content.

\section{An increase in the plasma membrane $\mathrm{PI}(4,5) \mathrm{P}_{2}$ level potentiated LDCV secretion in chromaffin cells}

PI4P5KI $\gamma$ is preferentially expressed in the nervous system and concentrated at synapses where it has been implicated in the synthesis of the $\mathrm{PI}(4,5) \mathrm{P}_{2}$ pool relevant for membrane trafficking (Wenk et al., 2001). We first examined the consequences of expressing PI4P5KI $\gamma$ fused to $\mathrm{mRFP}$ (mRFP-PI4P5KI $\gamma$ ) in PC12 cells. For convenience, we used PC12 cells for these measurements, because they can be transfected more easily than BCCs, without the need for a viral transfection system, and because all tested properties of GFP-PHPLC $\delta_{1}$ staining were very similar between PC12 cells and BCCs. Plasma membrane sheets were generated from transfected as well as from nontransfected cells and incubated with GFP-PH-PLC $\delta_{1}$. Expressed mRFP-PI4P5KI $\gamma$ was localized to the plasma membrane (Fig. $2 \mathrm{~B}$ ), in agreement with previous observations (Arioka et al., 2004). The fluorescence quantification revealed nearly threefold higher GFP-PH-PLC $\delta_{1}$ binding to membrane sheets from transfected cells (Fig. 2A-C). A similar increase in plasmalemmal $\mathrm{PI}(4,5) \mathrm{P}_{2}$ was detected using anti-PI $(4,5) \mathrm{P}_{2}$ antibody instead of GFP-PH-PLC $\delta_{1}$ (data not shown). These data show that overexpression of PI4P5KI $\gamma$ increased the level of $\mathrm{PI}(4,5) \mathrm{P}_{2}$ in the plasma membrane. Note that the GFP-PH-PLC $\delta_{1}$ labeling of the membrane sheets in Figure $2 A$ appears more uniform than in Figure $1 B$; this impression is caused by the scaling of the image to represent the very different fluorescence intensities present. After rescaling according to the intensity present within either sheet, both sheets showed inhomogeneous staining, although in the expressing cells, the inhomogeneities no longer appeared punctate (data not shown). When we compared the staining for GFP-PH-PLC $\delta_{1}$ (in the green channel) with the PI4P5KI $\gamma$ signal (in the red channel), we observed a significant correlation (Pearson correlation coefficient, $r=0.65 ; p<0.0001)$ between the binding of GFP-PHPLC $\delta_{1}$ and the level of PI4P5KI $\gamma$ overexpression (Fig. 2D).
$\mathrm{PI}, 5 \mathrm{P}_{2}$ in the plasma membrane
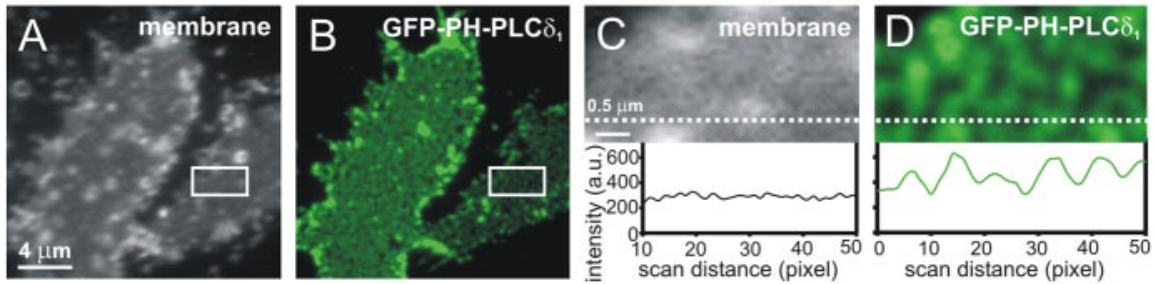

Specificity: 3x mutated GFP-PH-PLC $\delta_{1}$
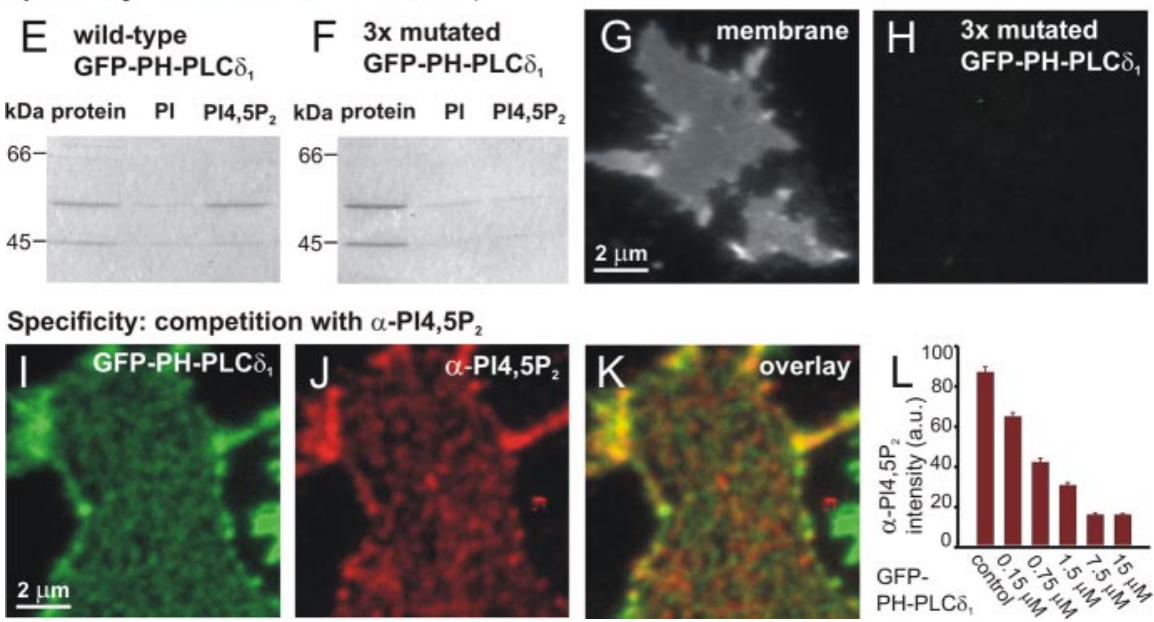

Figure 1. Punctate $\mathrm{PI}(4,5) \mathrm{P}_{2}$-specific staining of $\mathrm{PC} 12$ membrane sheets. $\boldsymbol{A}-\boldsymbol{D}$, Plasma membrane sheets were generated from PC12 cells, labeled with GFP-PH-PLC $\delta_{1}$, washed, and fixed. The samples were imaged in two channels: membranes were idenuniform. Bottom panels, The fluorescence intensities recorded along a line scan (dashed line) through the images (the fluores-

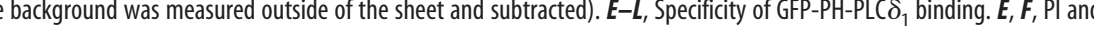
binding to $\mathrm{Pl}(4,5) \mathrm{P}_{2}$ liposomes, $\boldsymbol{G}, \boldsymbol{H}$, No staining $(<0.3 \%)$ was detected in the green channel when membrane sheets were dilution). I, GFP-PH-PLC $\delta_{1}$-stained sheet in the green channel. $J$, The same sheet, stained with $\left(y 5-\mathrm{PI}(4,5) \mathrm{P}_{2}\right.$ antibody and imaged in the dark red channel. $\boldsymbol{K}, 0$ verlay of $I$ and $\boldsymbol{J}$. Note that for display, each of the images $\boldsymbol{I} \boldsymbol{K} \boldsymbol{K}$ was scaled between the loca comparable (e.g., $\boldsymbol{B}$ and $\boldsymbol{I}$ are not comparable as far as absolute intensities are concerned). $\boldsymbol{L}$, Quantification of fluorescence (1:50 dilution) and increasing GFP-PH-PLC $\delta_{1}$ concentrations, the staining intensity of random images in the dark red [Cy5$\mathrm{PI}(4,5) \mathrm{P}_{2}$ antibody] channel decreased with increasing GFP-PH-PLC $\delta_{1}$ concentration.

To achieve high efficiency of BCC transfection, we expressed PI4P5KI $\gamma$ and GFP (as an expression marker) using Semliki Forest virus (SFV). Transfected cells were loaded via a patch pipette with the photolabile $\mathrm{Ca}^{2+}$ chelator nitrophenyl-EGTA and two $\mathrm{Ca}^{2+}$-sensitive dyes that enable accurate $\mathrm{Ca}^{2+}$ measurements during the whole-cell patch-clamp experiments (Voets, 2000). Flash photorelease of caged calcium commonly increased the intracellular calcium concentration $\left(\left[\mathrm{Ca}^{2+}\right]_{\mathrm{i}}\right)$ from several hundred nanomolars to $>10 \mu \mathrm{M}$, which resulted in robust secretion assayed by the increase in membrane capacitance and amperometric current (Fig. 3A). Measured by capacitance increase, exocytosis in the cells overexpressing PI4P5KI $\gamma$ was strongly enhanced (on average, 235\%) compared with control cells. Larger amperometric currents from PI4P5KI $\gamma$-overexpressing cells revealed that this strong increase in capacitance was mediated by fusion of catecholamine-filled LDCVs. A similar increase was observed as a result of a second stimulation executed $100 \mathrm{~s}$ after the first one (on average, 241\%). As described previously, BCC secretion elicited under these conditions consists of a burst phase 


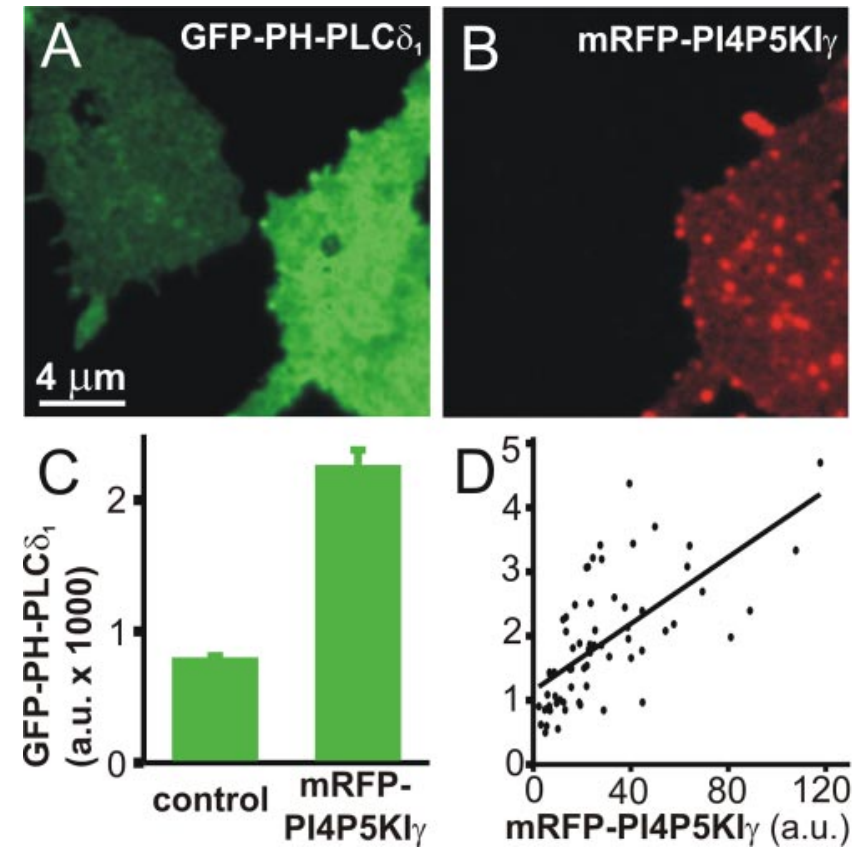

Figure 2. Overexpression of mRFP-PI4P5KI $\gamma$ increased the concentration of $\mathrm{PI}(4,5) \mathrm{P}_{2}$ in the plasma membrane. Plasma membrane sheets were generated from $\mathrm{PC} 12$ cells overexpressing mRFP-PI4P5Kl $\gamma$ for $24-36 \mathrm{~h}$, reacted with GFP-PH-PLC $\delta_{1}$, fixed, and imaged in the green $(\boldsymbol{A})$ and red $(\boldsymbol{B})$ channels. An increased $\mathrm{PI}(4,5) \mathrm{P}_{2}$ level was detected on the membrane sheets generated from mRFP-PI4P5KI $\gamma$-expressing cells. C, Quantitative determination of GFP-PH-PLC $\delta_{1}$ fluorescence intensity on membrane sheets from control and transfected cells from 65 sheets from two separate experiments (mean \pm SEM). $D, 0$ n membrane sheets such as those shown in $\boldsymbol{A}$ and $\boldsymbol{B}$, the staining intensity of random images in the green channel (GFP-PH-PLC $\delta_{1}$ ) was measured and plotted against the staining intensity in the red channel (mRFP-PI4P5KI $\gamma$ ). The line is a linear regression.

that corresponds to the emptying of two pools of releasecompetent vesicles (the RRP and the SRP, respectively) and a sustained phase that represents vesicle recruitment and subsequent fusion (Xu et al., 1998; Voets, 2000). In accordance with this model, we performed a kinetic analysis to determine the pool sizes (the amplitudes of the exponential fits) and fusion kinetics (time constants of the exponential fits) (Nagy et al., 2004). The sizes of both releasable pools, the RRP and the SRP, were increased by approximately a factor of 2 in PI4P5KI $\gamma$ overexpressing cells (Fig. $3 A$ ). Also, the sustained component of release, which measures the refilling of the pools, was significantly increased (Fig. 3A). In contrast, the time constants of RRP and SRP fusion did not differ significantly between control and PI4P5KI $\gamma$-overexpressing cells (Fig. $3 A$ ). These data indicate that the increased $\mathrm{PI}(4,5) \mathrm{P}_{2}$ level had an influence on the size and refilling of the releasable pools but not on their rate constant of fusion with the plasma membrane under conditions of elevated calcium concentrations.

We wanted to investigate whether a short-term (acute) increase in $\mathrm{PI}(4,5) \mathrm{P}_{2}$ would also modulate secretion. Therefore, we applied $5 \mu \mathrm{M} \mathrm{PI}(4,5) \mathrm{P}_{2}$ suspension through the patch pipette (Olsen et al., 2003). Cells loaded with $\mathrm{PI}(4,5) \mathrm{P}_{2}$ exhibited a large increase in secretion, both as a result of the first (on average, $275 \%$ increase) (Fig. $3 B$ ) and the second (on average, $270 \%$ increase) stimulus. Further kinetic analysis revealed that $\mathrm{PI}(4,5) \mathrm{P}_{2}$ loaded cells had a significantly larger exocytotic burst than the control, and, as in the case of PI4P5KI $\gamma$-overexpressing cells, this was a result of a twofold increase in the size of the RRP and the $\mathrm{SRP}$ in the absence of a change in fusion kinetics (Fig. $3 B$ ). The
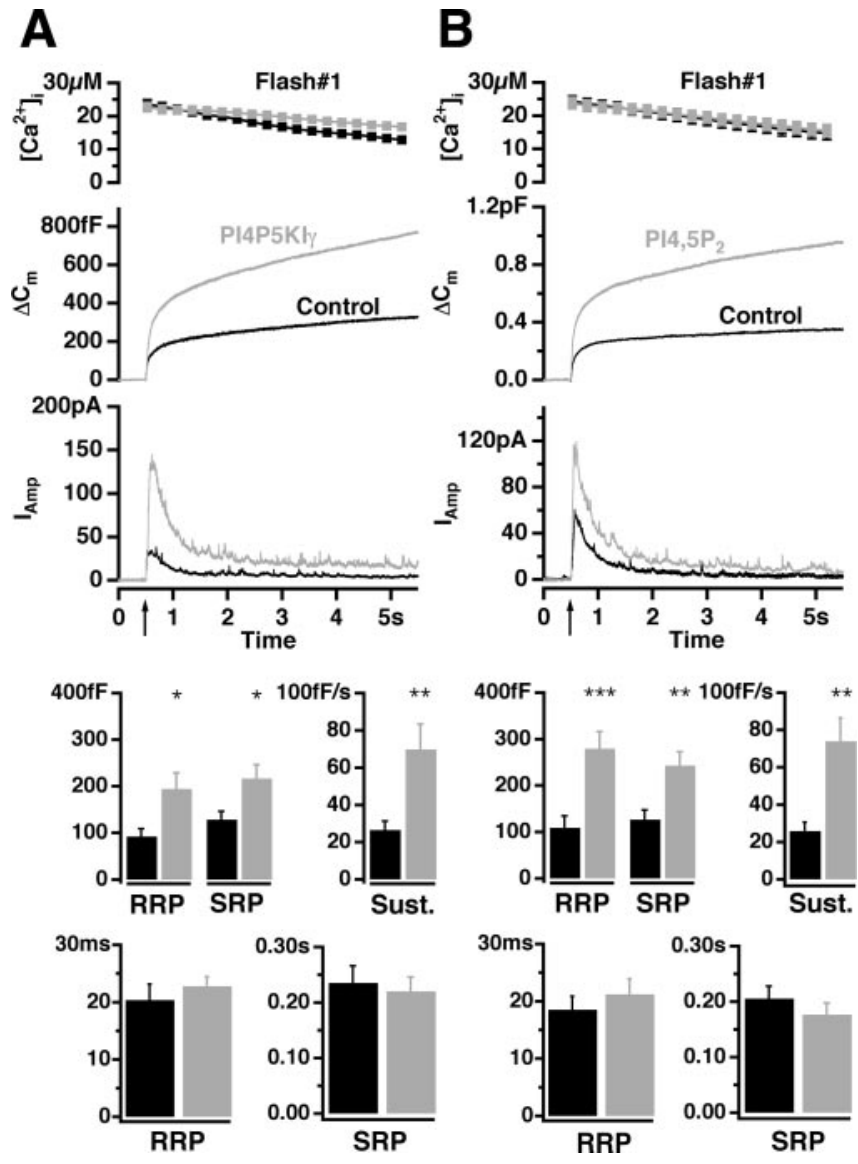

Figure 3. Overexpression of $\mathrm{PI} 4 \mathrm{P} 5 \mathrm{KI} \gamma$ or loading of $\mathrm{BCC}$ with $\mathrm{PI}(4,5) \mathrm{P}_{2}$ potentiated $\mathrm{LDCV}$ secretion. $\boldsymbol{A}, \boldsymbol{B}$, Top, Mean $\left[\mathrm{Ca}^{2+}\right]_{\mathrm{i}}$ (top; error bars represent $\left.\mathrm{SEM}\right)$, capacitance change (middle), and amperometric current (bottom) were measured simultaneously after a step-like elevation of $\left[\mathrm{Ca}^{2+}\right]_{i}$ caused by flash photolysis of caged $\mathrm{Ca}^{2+}$ (flash at arrow). The traces are averages of many experiments, so the individual fusion events (spikes) are not recognizable in the amperometric signal. $\boldsymbol{A}$, Secretion from BCCs after the first flash photorelease of calcium. The means of 34 control cells (black) and 34 cells overexpressing PI4P5KI $\gamma$ for 12-16 h (gray) are shown. There was no difference in preflash $\left[\mathrm{Ca}^{2+}\right]_{\mathrm{i}}$ between the two groups (data not shown). Secretion in transfected cells was strongly potentiated. Bottom, amplitudes and time constants of exponential fits to individual responses. The amplitudes (mean \pm SEM) of the two releasable pools (RRP and SRP) and the rate of sustained component were significantly increased in cells overexpressing PI4P5KI $\gamma$ (gray bars) $\left({ }^{*} p<0.05 ;{ }^{* *} p<0.01 ;{ }^{* * *} p<0.001\right.$ ). In contrast, time constants were similar between control cells and $\mathrm{BCC} s$ overexpressing $\mathrm{PI} 4 \mathrm{P} 5 \mathrm{KI} \gamma$. $\boldsymbol{B}$, Intracellular application of $\mathrm{PI}(4,5) \mathrm{P}_{2}$ strongly potentiated secretion. The response to a first flash stimulation in control cells (black trace; $n=26$ ) and cells loaded with $5 \mu \mathrm{m}$ $\mathrm{PI}(4,5) \mathrm{P}_{2}$ (gray trace; $n=27$ ) is shown. Bottom, Significant increase in amplitudes of the RRP and the SRP as well as in the rate of sustained component was detected. Time constants were unchanged.

increase in the rate of sustained release from $\mathrm{PI}(4,5) \mathrm{P}_{2}$-loaded cells was also highly significant (Fig. 3B). Given that intracellular application of $\mathrm{PI}(4,5) \mathrm{P}_{2}$ affects exocytosis, we inspected whether $\mathrm{PI}(4,5) \mathrm{P}_{2}$ could be incorporated in the plasma membrane when incubated in vitro with plasma membrane sheets generated from BCCs and PC12 cells. The sheets were incubated with different concentrations of $\mathrm{PI}(4,5) \mathrm{P}_{2}$ suspension and subsequently reacted with GFP-PH-PLC $\delta_{1}$. We detected fluorescent particles attached to the membrane sheets, but plasmalemmal $\mathrm{PI}(4,5) \mathrm{P}_{2}$ was not significantly increased, indicating that insertion of $\mathrm{PI}(4,5) \mathrm{P}_{2}$ was not very efficient in this in vitro experiment (data not shown). Nevertheless, we expect that in an in vivo situation, cytoplasmic proteins such as PITP would mediate insertion of $\mathrm{PI}(4,5) \mathrm{P}_{2}$ into the membrane. 


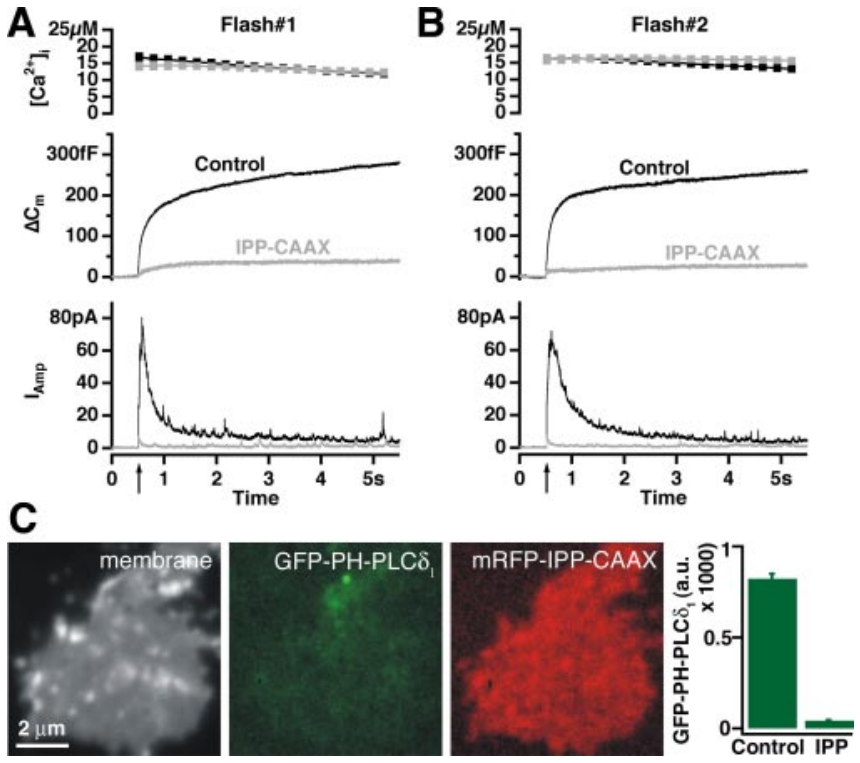

Figure 4. Depletion of plasma membrane $\mathrm{PI}(4,5) \mathrm{P}_{2}$ abolished $\mathrm{LDCV}$ secretion in $\mathrm{BCC}$. $\boldsymbol{A}$, Response to a first flash stimulation in control cells (black trace; $n=53$ ) and cells overexpressing IPP1-CAAX for $9-13 \mathrm{~h}$ (gray trace; $n=52$ ). Secretion in transfected cells was almost abolished. $\boldsymbol{B}, \mathrm{A}$ second flash stimulation given $2 \mathrm{~min}$ after the first one gave the same result (black trace, 54 control cells; gray trace, 53 cells overexpressing IPP1-CAAX). C, PI(4,5)P 2 depletion from plasma membrane of $\mathrm{PC} 12$ cells. Plasma membrane sheets were generated from $\mathrm{PC} 12$ cells overexpressing mRFP-IPP1-CAAX for $30 \mathrm{~h}$, reacted with GFP-PH-PLC $\delta_{1}$, fixed, and imaged in the presence of TMA-DPH dye in the blue, green, and red channels. Barely any GFP-PH-PLC $\delta_{1}$ signal could be detected on membrane sheets generated from mRFP-IPP1-CAAX-expressing cells. The graph shows quantitative determination of GFP-PH-PLC $\delta_{1}$ fluorescence on membrane sheets from control (71 sheets) and transfected ( 58 sheets) cells from two experiments (mean \pm SEM).

Together, these data demonstrate that increasing the amount of plasmalemmal $\mathrm{PI}(4,5) \mathrm{P}_{2}$ over control conditions caused a higher level of LDCV secretion and that this increase is attributable to a larger number of primed vesicles.

\section{Deprivation of $\mathrm{PI}(4,5) \mathrm{P}_{2}$ from plasma membrane abolished LDCV secretion in chromaffin cells}

We next asked whether normal secretion in resting chromaffin cells depends on the presence of $\mathrm{PI}(4,5) \mathrm{P}_{2}$. To decrease the $\mathrm{PI}(4,5) \mathrm{P}_{2}$ concentration in the plasma membrane, we overexpressed a $\mathrm{PI}(4,5) \mathrm{P}_{2}$ degrading enzyme, the membrane-targeted inositol 5-phosphatase domain of synaptojanin 1 (IPP1-CAAX) fused to mRFP (mRFP-IPP1-CAAX) (Krauss et al., 2003) in PC12 cells. Plasma membrane sheets were generated from these as well as from nontransfected cells and reacted with GFP-PH$\operatorname{PLC} \delta_{1}$. The fluorescence quantification revealed that almost no signal could be detected on the membrane sheets generated from mRFP-IPP1-CAAX-expressing cells (on average, 5.2\% of control values) (Fig. 4C). Similar data were obtained using an anti$\mathrm{PI}(4,5) \mathrm{P}_{2}$ antibody (data not shown). Thus, overexpression of mRFP-IPP1-CAAX almost completely deprived $\mathrm{PI}(4,5) \mathrm{P}_{2}$ from PC12 cell plasma membrane.

We constructed SFV encoding IPP1-CAAX and GFP and transfected BCCs in primary culture. $\mathrm{Ca}^{2+}$-induced secretion from BCCs expressing IPP1-CAAX was nearly abolished, when evaluated as both a capacitance change and as amperometric current (Fig. 4A). The total secretion over the first $5 \mathrm{~s}$ recording period added up to $\sim 13 \%$ of that seen in control cells. Also, a second stimulation $\sim 2$ min after the first one failed to elicit secretion (Fig. $4 B$ ). We therefore conclude that $\mathrm{PI}(4,5) \mathrm{P}_{2}$ is essen- tial for $\mathrm{Ca}^{2+}$-induced LDCV secretion. Because of the low amount of remaining secretion, a kinetic analysis was not possible.

Next, we examined whether the $\mathrm{Ca}^{2+}$-induced secretion in BCCs overexpressing IPP1-CAAX could be rescued by loading the cells with $5 \mu \mathrm{M} \mathrm{PI}(4,5) \mathrm{P}_{2}$ through the patch pipette. In approximately one-quarter of the experimental cells, we managed to rescue secretion up to normal levels, whereas in approximately three-quarters of the cells, this was not the case (data not shown), probably because of the continuous action of IPP1-CAAX to break down $\mathrm{PI}(4,5) \mathrm{P}_{2}$.

The previous two sections show that the resting level of $\mathrm{PI}(4,5) \mathrm{P}_{2}$ in the inner leaflet of the plasma membrane is intermediate between the levels that would result in minimal and maximal secretion. Thus, the level of secretion can be changed in both directions by a change in $\mathrm{PI}(4,5) \mathrm{P}_{2}$, making $\mathrm{PI}(4,5) \mathrm{P}_{2}$ a likely key physiological regulator of chromaffin cell secretion.

\section{Dual effect of LY294002 on the plasma membrane PI(4,5) $\mathrm{P}_{2}$ level and LDCV secretion in chromaffin cells}

Besides $\mathrm{PI}(4,5) \mathrm{P}_{2}$, other phosphoinositides may have a role in secretion (Cremona and De Camilli, 2001). Based on the use of phosphatidylinositol 3-kinase (PI3K) inhibitors, several studies suggested PI3K and 3-phosphorylated phosphatidylinositides in regulating exocytosis and synaptic transmission (ChasserotGolaz et al., 1998; Hong and Chang, 1999; Rizzoli and Betz, 2002; Cousin et al., 2003). Therefore, we examined the effect of the most commonly used PI3K inhibitor, LY294002, on catecholamine secretion in BCCs. Acute application of $100 \mu \mathrm{M}$ LY294002 was performed through a local perfusion system. Measured by capacitance increase, the first $\mathrm{Ca}^{2+}$-releasing stimulus applied 4 min after the beginning of LY294002 application showed strongly enhanced secretion in treated cells (on average, 235\%) (Fig. 5A). The sizes of both the releasable pools were increased; the rate of the sustained component was, on average, higher in LY294002treated cells, but this was not statistically significant. The time constants for fusion of the releasable pools were indistinguishable from control cells (Fig. 5A). The second flash given $100 \mathrm{~s}$ after the first one also evoked an increased exocytotic response (on average, $242 \%$ ). These findings are surprising, because it was previously shown that LY294002 inhibited secretion in chromaffin cells (Chasserot-Golaz et al., 1998); in that study, longer incubation times were used. Therefore, we increased the preincubation time to $30-70 \mathrm{~min}$ and indeed this resulted in a $58 \%$ reduction of secretion at the first stimulus and a $72 \%$ reduction at the second one (Fig. 5B). Kinetic analysis revealed that the sizes of both releasable pools as well as the rate of sustained secretion were significantly decreased after prolonged application of LY294002 (Fig. 5B). Moreover, inspection of the time constants revealed no differences in fusion kinetics with respect to control for both the RRP and the SRP (Fig. 5B).

We wanted to determine whether the effect of LY294002 could be accounted for by changes in the $\mathrm{PI}(4,5) \mathrm{P}_{2}$ level. We therefore measured the corresponding $\mathrm{PI}(4,5) \mathrm{P}_{2}$ levels in plasma membrane sheets from BCCs (Fig. 5C) or PC12 cells treated with LY294002 for defined time periods. For both BCC and PC12 cell plasma membranes, a nearly twofold increase in GFP-PH-PLC $\delta_{1}$ binding was observed after short-term incubation with LY294002 (3-5 min) (Fig. 5D, data from BCC; data from PC12 cells were similar). Prolonged incubation with LY294002 resulted in a $\sim 50 \%$ decrease in GFP-PH-PLC $\delta_{1}$ binding $(30-60 \mathrm{~min}$ ) (Fig. $5 D)$. We performed the same experiment with $100 \mu \mathrm{M} \mathrm{2-(4-}$ piperazinyl)-8-phenyl-4H-1-benzopyran-4-one (LY303511), an 
A
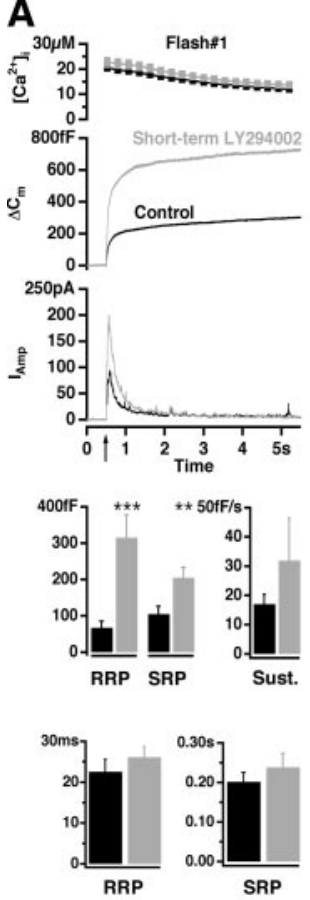

B
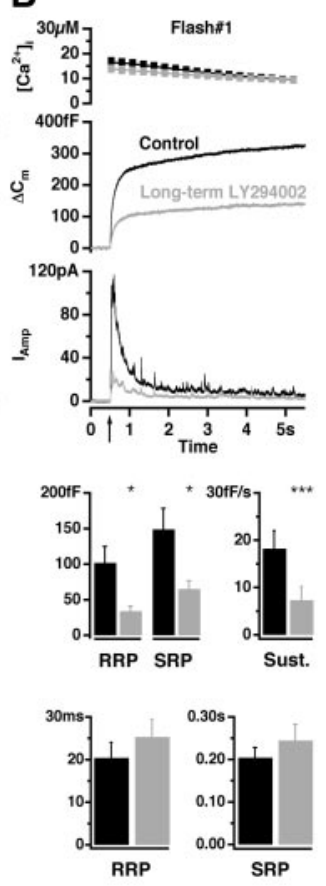
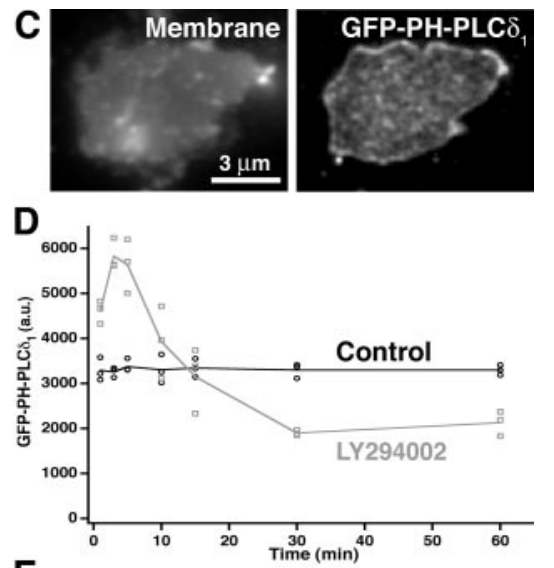

E

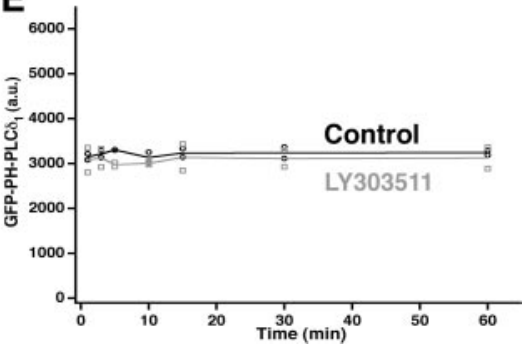

Figure 5. Dual effect of LY294002 on the plasma membrane PI(4,5) $\mathrm{P}_{2}$ level and LDCV secretion in chromaffin cells. $\boldsymbol{A}$, Shortterm (4 min) application of $100 \mu \mathrm{m}$ LY294002. The response to the first stimulation in control cells (black; 33 cells) and BCCs perfused with LY294002 (gray; 31 cells) is shown. For an explanation, see the legend to Figure 3. A significant increase in RRP and SRP amplitudes was seen when LY294002 was applied, but no difference in the rate of the sustained component or time constants was found. $\boldsymbol{B}$, Long-term application (30-70 min) of $100 \mu \mathrm{M} \mathrm{LY} 294002$. The response to the first flash stimulation in control cells (black; 29 cells) and BCCs preincubated with LY294002 (gray; 30 cells) is shown. A significant decrease in the total secretion was found; the time constants were indistinguishable from control cells. C, Example plasma membrane sheets generated from BCCs and labeled with GFP-PH-PLC $\delta_{1}$. The samples were imaged in two channels: membranes were identified in the presence of TMA-DPH dye in the blue channel and GFP-PH-PLC $\delta_{1}$ in the green channel. $\boldsymbol{D}$, LY294002 induced a transient increase that was followed by a decrease of $\mathrm{PI}(4,5) \mathrm{P}_{2}$ content in the plasma membrane. BCCs were incubated with $100 \mu \mathrm{m} L \mathrm{Y} 294002$ in extracellular buffer or extracellular buffer only (control) for the time intervals indicated, and membrane sheets were generated, labeled with GFP-PH-PLC $\delta_{1}$, and fixed. The experiment was repeated three times. The staining intensity of $>50$ sheets from each experiment was measured in the green channel and plotted against time. $\boldsymbol{E}$, The same sheet experiment was performed with $100 \mu \mathrm{m}$ LY303511, an inactive analog of LY294002. No difference in GFP-PH-PLC $\delta_{1}$ binding compared with control was detected.

inactive analog of LY294002, and observed no difference in GFPPH-PLC $\delta_{1}$ binding compared with control (Fig. $5 E$ ). Therefore, we conclude that changes of the $\mathrm{PI}(4,5) \mathrm{P}_{2}$ level in the plasma membrane were because of the specific activities of LY294002.

In conclusion, LY294002 has a biphasic effect on secretion: acute application leads to increased $\mathrm{PI}(4,5) \mathrm{P}_{2}$ levels and potentiation of secretion, whereas chronic application decreases $\mathrm{PI}(4,5) \mathrm{P}_{2}$ levels and inhibits secretion.

\section{Discussion}

By comparing secretion from chromaffin cells using electrophysiological methods with inner membrane leaflet $\mathrm{PI}(4,5) \mathrm{P}_{2}$ levels using a membrane sheet assay, we have shown that the $\mathrm{PI}(4,5) \mathrm{P}_{2}$ level determines the extent of chromaffin cell secretion. If $\mathrm{PI}(4,5) \mathrm{P}_{2}$ is depleted from the plasma membrane by phosphatase overexpression or long-term LY294002 application, secretion is reduced. If $\mathrm{PI}(4,5) \mathrm{P}_{2}$ levels are increased by PI4P5KI $\gamma$ overexpression, $\mathrm{PI}(4,5) \mathrm{P}_{2}$ infusion, or short-term LY294002 application, secretion is increased. This shows that (1) short-term (acute) and long-term (chronic) changes in $\mathrm{PI}(4,5) \mathrm{P}_{2}$ levels are equally effective at modulating secretion, therefore (2) the cells do not seem to compensate for a change in the $\mathrm{PI}(4,5) \mathrm{P}_{2}$ level but rather use it as an input signal to determine the extent of secretion, and (3) in the normal, resting chromaffin cells the $\mathrm{PI}(4,5) \mathrm{P}_{2}$ level is suboptimal, so that an increase can upregulate secretion. All of these features make $\mathrm{PI}(4,5) \mathrm{P}_{2}$ a potential key physiological regulator of secretion.

\section{Spatial distribution of $\mathrm{PI}(4,5) \mathrm{P}_{2}$ in the plasma membrane}

We wanted to develop methods for assaying plasma membrane $\mathrm{PI}(4,5) \mathrm{P}_{2}$ levels and distribution. In many studies, it is hard to distinguish between the roles of $\mathrm{PI}(4,5) \mathrm{P}_{2}$ and that of related phosphatidylinositides $\left[\mathrm{PI}(4) \mathrm{P}, \mathrm{PI}(3,4,5) \mathrm{P}_{3}\right]$ on secretion. Likewise, the question of the spatial distribution of $\mathrm{PI}(4,5) \mathrm{P}_{2}$ in the membrane remains unresolved. The presence of $\mathrm{PI}(4,5) \mathrm{P}_{2}$ domains has been proposed by several groups (for review, see Caroni, 2001; Martin, 2001). However, the results of overexpression studies using $\mathrm{PH}$ domains are diverse. In the first studies, a nearly uniform distribution over the plasma membrane was found (Stauffer et al., 1998; Várnai and Balla, 1998). Some later studies that revealed local accumulations in plasma membrane "ruffles" (Honda et al., 1999; Botelho et al., 2000; Tall et al., 2000) were recently reinterpreted after the demonstration of colocalization with lipophilic membrane dyes, implying that the apparent $\mathrm{PI}(4,5) \mathrm{P}_{2}$ enrichments might have been local membrane infoldings (van Rheenen and Jalink, 2002). Várnai et al. (2002) found that another PH domain from the PLC-like protein p130 did not become localized to the plasma membrane, although it showed selective binding to $\mathrm{PI}(4,5) \mathrm{P}_{2}$ in vitro. It was suggested that a proteinaceous factor contributes to the plasma membrane localization of GFP-PH-PLC $\delta_{1}$. However, the interpretation of expression studies is difficult, because the localization of a soluble protein in a living cell is determined by the relative affinities, amounts, and accessibilities of all of the different ligands [for PH-PLC $\delta_{1}$ and $\mathrm{PH}-$ p130, also the soluble inositol $(1,4,5)$ triphosphate], the concentration of the overexpressed protein, and the way that the cell responds to the sequestering of the ligands.

We therefore favored to detect plasmalemmal $\mathrm{PI}(4,5) \mathrm{P}_{2}$ by an in vitro assay in which exogeneous probe was added to isolated membrane sheets, in which only a single high-affinity ligand is present $\left[\mathrm{PI}(4,5) \mathrm{P}_{2}\right]$. Our experiments show that $\mathrm{PI}(4,5) \mathrm{P}_{2}$ binding of $\mathrm{PH}-\mathrm{PLC} \delta_{1}$ is necessary for membrane binding, that $\mathrm{PH}$ $\mathrm{PLC} \delta_{1}$ competes with an anti-PI $(4,5) \mathrm{P}_{2}$ antibody for plasma membrane binding, and that the assay could detect chronic as well as acute increases in $\mathrm{PI}(4,5) \mathrm{P}_{2}$. The following features characterize the spatial organization of $\mathrm{PI}(4,5) \mathrm{P}_{2}$ in the membrane sheets of chromaffin and PC12 cells: (1) $\mathrm{PI}(4,5) \mathrm{P}_{2}$ was apparently enriched in abundant submicrometer-sized clusters; and (2) cholesterol was necessary for the organization of $\mathrm{PI}(4,5) \mathrm{P}_{2}$ clusters. Our GFP-PH-PLC $\delta_{1}$ clusters in the plasma membrane did not correspond to local increases in membrane area, as shown by TMA-DPH or DiIC ${ }_{16}$ staining (Fig. $1 A-D$ ). Being approximately punctate, these domains appear similar to those that were de- 
scribed by Laux et al. (2000) to colocalize with $\mathrm{PI}(4,5) \mathrm{P}_{2}$-binding GAP43, MARCKS, and CAP23 (the GMC proteins) in PC12 cells. It should be pointed out that the punctate staining of GFP-PHPLC $\delta_{1}$ can be interpreted in several ways: the most obvious is that it reflects a punctate $\mathrm{PI}(4,5) \mathrm{P}_{2}$ distribution in the plasma membrane. However, it is also possible that it reflects varying accessibility of the probe to plasmalemmal $\mathrm{PI}(4,5) \mathrm{P}_{2}$, caused by steric hindrance attributable to endogeneous $\mathrm{PI}(4,5) \mathrm{P}_{2}$-associated proteins. In this case, the punctate labeling may reflect an inhomogeneous protein distribution in the membrane, rather than an inhomogeneous $\mathrm{PI}(4,5) \mathrm{P}_{2}$ distribution.

\section{$\mathrm{PI}(4,5) \mathrm{P}_{2}$ and exocytosis}

We found that $\mathrm{PI}(4,5) \mathrm{P}_{2}$ positively modulates secretion in neuroendocrine cells, in agreement with previous studies (Eberhard et al., 1990; Holz et al., 2000; Aikawa and Martin, 2003; Olsen et al., 2003). A number of different manipulations of the $\mathrm{PI}(4,5) \mathrm{P}_{2}$ level all showed that $\mathrm{PI}(4,5) \mathrm{P}_{2}$ stimulates exocytosis by increasing the number of vesicles residing in the releasable vesicle pools and increasing the sustained rate of release, which is assumed to be indicative of an increased refilling rate of the releasable pools. This is in agreement with the finding that $\mathrm{PI}(4,5) \mathrm{P}_{2}$ infusion into pancreatic $\beta$-cells increases the RRP size (Olsen et al., 2003).

Overexpression of PI4P5KI $\gamma$, the kinase that generates $\mathrm{PI}(4,5) \mathrm{P}_{2}$, caused an increase in the plasmalemmal $\mathrm{PI}(4,5) \mathrm{P}_{2}$ level, whereas overexpression of a membrane-tagged $\mathrm{PI}(4,5) \mathrm{P}_{2}$ phosphatase, IPP1-CAAX, eliminated plasmalemmal $\mathrm{PI}(4,5) \mathrm{P}_{2}$ and secretion. Thus, the balance between generation and degradation rates of plasmalemmal $\mathrm{PI}(4,5) \mathrm{P}_{2}$ directly regulates the extent of LDCV secretion from chromaffin cells. The implication is that $\mathrm{PI}(4,5) \mathrm{P}_{2}$ is more than an obligatory-permissive factor that needs to be present at sufficient levels in order for exocytosis to occur. Rather, $\mathrm{PI}(4,5) \mathrm{P}_{2}$ levels are limiting secretion in the control situation, and therefore changes in this level regulate secretion directly and dynamically.

A time-dependent correlation between the plasma membrane $\mathrm{PI}(4,5) \mathrm{P}_{2}$ level and primed vesicle pool size was found in our experiments with LY294002. Two previous studies addressed the effect of LY294002 on neuroendocrine secretion. When applied for $30 \mathrm{~min}$, LY294002 did not significantly affect secretion in permeable PC12 cells (Martin et al., 1997). However, ChasserotGolaz et al. (1998) described a dose-dependent inhibition of catecholamine secretion in chromaffin cells after a 30 min incubation with LY294002 and implied that PI3K is involved in secretion. In agreement with the latter study, we found that preincubation (30-70 min) with LY294002 inhibited secretion. However, in addition we discovered that short-term application of LY294002 (up to 6-7 $\mathrm{min}$ ) caused a more than twofold increase in the number of fused vesicles. Taking advantage of our $\mathrm{PI}(4,5) \mathrm{P}_{2}$ assay, we found that the short-term application of LY294002 induced a transient increase in the level of PI $(4,5) \mathrm{P}_{2}$ in the plasma membrane, whereas a longer preincubation decreased it significantly. Together with the overexpression studies, this correlation suggests that the effect of LY294002 on secretion is mediated through a change in the plasmalemmal $\mathrm{PI}(4,5) \mathrm{P}_{2}$ level. However, the pathway through which this biphasic change in the $\mathrm{PI}(4,5) \mathrm{P}_{2}$ level comes about was not identified by our experiments. LY294002 is an inhibitor of PI3K that uses $\mathrm{PI}(4,5) \mathrm{P}_{2}$ as a substrate to generate $\mathrm{PI}(3,4,5) \mathrm{P}_{3}$ (Vlahos et al., 1994). $\mathrm{PI}(3,4,5) \mathrm{P}_{3}$ may affect the PI $(4,5) \mathrm{P}_{2}$ metabolism by activating PLC $\gamma$ (Bae et al., 1998). However, LY294002 also inhibits PI4K, which generates $\mathrm{PI}(4) \mathrm{P}$, the precursor for $\mathrm{PI}(4,5) \mathrm{P}_{2}$ (Downing et al., 1996; Sorensen et al., 1998). Therefore, LY294002 inhibits at least two pathways of phosphatidylinositide metabolism, which could lead to complex time-dependent effects on the PI $(4,5) \mathrm{P}_{2}$ level. In addition, LY294002 affects other kinases (e.g., casein kinase 2) (Davies et al., 2000), which may have indirect effects on $\mathrm{PI}(4,5) \mathrm{P}_{2}$ metabolism. Whatever the pathway for LY294002 action, our data show that the effect of this inhibitor on secretion may be accounted for by changes in $\mathrm{PI}(4,5) \mathrm{P}_{2}$ levels, without the need to invoke a direct role for 3-phosphorylated phosphatidylinositides in exocytosis. In addition, this experiment shows that the size of the primed vesicle pools in chromaffin cells can respond to transient changes in the $\mathrm{PI}(4,5) \mathrm{P}_{2}$ level on the minute time scale. This is consistent with a function of $\mathrm{PI}(4,5) \mathrm{P}_{2}$ as an acute regulator of secretion.

Several proteins involved in exocytosis specifically bind $\mathrm{PI}(4,5) \mathrm{P}_{2}$ : the family of synaptotagmin proteins (Schiavo et al., 1996), $\mathrm{Ca}^{2+}$-dependent activator protein for secretion (CAPS) (Loyet et al., 1998), Mint (Okamoto and Sudhof, 1997), and rabphilin 3 (Chung et al., 1998). Which of these interactions are physiologically relevant remains to be explored. The recent finding that synaptotagmin 1 binds to $\mathrm{PI}(4,5) \mathrm{P}_{2}$-containing membranes via its $\mathrm{C} 2 \mathrm{~B}$ domain, and thereby increases its speed of insertion into that membrane, led to the suggestion that changes in the $\mathrm{PI}(4,5) \mathrm{P}_{2}$ level could regulate release rates (Bai et al., 2004). We found that under conditions of increased or decreased $\mathrm{PI}(4,5) \mathrm{P}_{2}$ levels, the releasable vesicle pool sizes were changed but the release rate constants were not. It was previously shown that fusion of vesicles from the RRP is dependent of synaptotagmin 1 (Voets et al., 2001) and that the release rate constant can be modified by synaptotagmin 1 mutation (Sørensen et al., 2003). Therefore, the simplest explanation for our findings is that $\mathrm{PI}(4,5) \mathrm{P}_{2}$ binding of synaptotagmin 1 is not rate limiting for fusion triggering under our conditions. An interesting possibility would be that $\mathrm{PI}(4,5) \mathrm{P}_{2}$ binding of synaptotagmin 1 is involved in upstream reactions. Additional studies are required to answer this question.

In conclusion, we report that $\mathrm{PI}(4,5) \mathrm{P}_{2}$ is in a position to be a key physiological regulator of the size and the refilling rate of the primed vesicle pools but not the fusion rate constants. As a secretion regulator, $\mathrm{PI}(4,5) \mathrm{P}_{2}$ has several advantages over proteins with the same task: plasmalemmal $\mathrm{PI}(4,5) \mathrm{P}_{2}$ molecules could recruit and activate a large number of different proteins to create a local environment in which exocytosis takes place. At the same time, the rapid enzymatic production and degradation of $\mathrm{PI}(4,5) \mathrm{P}_{2}$ allows the cell to remain flexible: by changing the $\mathrm{PI}(4,5) \mathrm{P}_{2}$ level, physiological function can be modified within seconds or minutes without the need for protein synthesis or degradation.

\section{References}

Aikawa Y, Martin TFJ (2003) ARF6 regulates a plasma membrane pool of phosphatidylinositol $(4,5)$ bisphosphate required for regulated exocytosis. J Cell Biol 162:647-659.

Arioka M, Nakashima S, Shibasaki Y, Kitamoto K (2004) Dibasic amino acid residues at the carboxy-terminal end of kinase homology domain participate in the plasma membrane localization and function of phosphatidylinositol 5-kinase $\gamma$. Biochem Biophys Res Commun 319:456-463.

Ashery U, Betz A, Xu T, Brose N, Rettig J (1999) An efficient method for infection of adrenal chromaffin cells using the Semliki Forest virus gene expression system. Eur J Cell Biol 78:525-532.

Avery J, Ellis DJ, Lang T, Holroyd P, Riedel D, Henderson RM, Edwardson JM, Jahn R (2000) A cell-free system for regulated exocytosis in PC12 cells. J Cell Biol 148:317-324.

Bae YS, Cantley LG, Chen CS, Kim SR, Kwon KS, Rhee SG (1998) Activation of phospholipase $\mathrm{C} \gamma$ by phosphatidylinositol 3,4,5-trisphosphate. J Biol Chem 273:4465-4469.

Bai J, Tucker WC, Chapman ER (2004) PIP $_{2}$ increases the speed of response of synaptotagmin and steers its membrane-penetration activity toward the plasma membrane. Nat Struct Mol Biol 11:36-44. 
Botelho RJ, Teruel M, Dierckman R, Anderson R, Wells A, York JD, Meyer T, Grinstein S (2000) Localized biphasic changes in phosphatidylinositol4,5-bisphosphate at sites of phagocytosis. J Cell Biol 151:1353-1368.

Caroni P (2001) New EMBO members' review: actin cytoskeleton regulation through modulation of $\mathrm{PI}(4,5) \mathrm{P}(2)$ rafts. EMBO J 20:4332-4336.

Chasserot-Golaz S, Hubert P, Thierse D, Dirrig S, Vlahos CJ, Aunis D, Bader M-F (1998) Possible involvement of phosphatidylinositol 3-kinase in regulated exocytosis: studies in chromaffin cells with inhibitor LY294002. J Neurochem 70:2347-2355.

Chung SH, Song WJ, Kim K, Bednarski JJ, Chen J, Prestwich GD, Holz RW (1998) The C2 domains of Rabphilin3A specifically bind phosphatidylinositol 4,5-bisphosphate containing vesicles in a $\mathrm{Ca}^{2+}$-dependent manner. In vitro characteristics and possible significance. J Biol Chem 273:10240-10248.

Cousin MA, Malladi CS, Tan TC, Raymond CR, Smillie KJ, Robinson PJ (2003) Synapsin I-associated phosphatidylinositol 3-kinase mediates synaptic vesicle delivery to the readily releasable pool. J Biol Chem 278:29065-29071.

Cremona O, De Camilli P (2001) . Phosphoinositides in membrane traffic at the synapse. Phosphoinositides in membrane traffic at the synapse. J Cell Sci 1041-1052.

Davies SP, Reddy H, Caivano M, Cohen P (2000) Specificity and mechanism of action of some commonly used protein kinase inhibitors. Biochem J 351:95-105.

Downing GJ, Kim S, Nakanishi S, Catt KJ, Balla T (1996) Characterization of a soluble adrenal phosphatidylinositol 4-kinase reveals wortmannin sensitivity of type III phosphatidylinositol kinases. Biochemistry 35:3587-3594.

Eberhard DA, Cooper CL, Low MG, Holz RW (1990) Evidence that the inositol phospholipids are necessary for exocytosis. Loss of inositol phospholipids and inhibition of secretion in permeabilized cells caused by a bacterial phospholipase C and removal of ATP. Biochem J 268:15-25.

Hay JC, Martin TF (1993) Phosphatidylinositol transfer protein required for ATP-dependent priming of calcium activated secretion. Nature 366:572-575.

Hay JC, Fisette PL, Jenkins GH, Fukami K, Takenawa T, Anderson RA, Martin TF (1995) ATP-dependent inositide phosphorylation required for calcium activated secretion. Nature 34:173-177.

Holz RW, Bittner MA, Peppers SC, Senter RA, Eberhard DA (1989) MgATP-independent and MgATP-dependent exocytosis. Evidence that MgATP primes adrenal chromaffin cells to undergo exocytosis. J Biol Chem 264:5412-5419.

Holz RW, Hlubek MD, Sorensen SD, Fisher SK, Balla T, Ozaki S, Prestwich GD, Stuenkel EL, Bittner MA (2000) A pleckstrin homology domain specific for phosphatidylinositol 4,5-bisphosphate (PtdIns-4,5-P2) and fused to green fluorescent protein identifies plasma membrane PtdIns4,5-P2 as being important in exocytosis. J Biol Chem 275:17878-17885.

Honda A, Nogami M, Yokozeki T, Yamazaki M, Nakamura H, Watanabe H, Kawamoto K, Nakayama K, Morris AJ, Frohman MA, Kanaho Y (1999) Phosphatidylinositol 4-phosphate 5-kinase $\alpha$ is a downstream effector of the small G protein ARF6 in membrane ruffle formation. Cell 99:521-532.

Hong SJ, Chang CC (1999) Inhibition of quantal release from motor nerve by wortmannin. Br J Pharmacol 128:142-148.

Krauss M, Kinua M, Wenk MR, De Camilli P, Takei K, Haucke V (2003) ARF6 stimulates clathrin/AP-2 recruitment to synaptic membranes by activating phosphatidylinositol phosphate kinase type I $\gamma$. J Cell Biol 162:113-124

Lang T, Wacker I, Steyer J, Kaether C, Wunderlich I, Soldati T, Gerdes HH, Almers W (1997) $\mathrm{Ca}^{2+}$-triggered peptide secretion in single cells imaged with green fluorescent protein and evanescent-wave microscopy. Neuron 18:857-863.

Lang T, Bruns D, Wenzel D, Riedel D, Holroyd P, Thiele C, Jahn R (2001) SNAREs are concentrated in cholesterol-dependent clusters that define docking and fusion sites for exocytosis. EMBO J 20:2202-2213.

Lang T, Margittai M, Holzler H, Jahn R (2002) SNAREs in native plasma membranes are active and readily form core complexes with endogenous and exogenous SNAREs. J Cell Biol 158:751-760.

Laux T, Fukami K, Thelen M, Golub T, Frey D, Caroni P (2000) GAP43, MARCKS, and CAP23 modulate $\mathrm{PI}(4,5) \mathrm{P}(2)$ at plasmalemmal rafts, and regulate cell cortex actin dynamics through a common mechanism. J Cell Biol 149:1455-1472.

Loyet KM, Kowalchyk JA, Chaudhary A, Chen J, Prestwich GD, Martin TF (1998) Specific binding of phosphatidylinositol 4,5-bisphosphate to calcium-dependent activator protein for secretion (CAPS), a potential phosphoinositide effector protein for regulated exocytosis. J Biol Chem 273:8337-8343.

Martin TF (2001) PI(4,5) $\mathrm{P}(2)$ regulation of surface membrane traffic. Curr Opin Cell Biol 13:493-499.

Martin TF, Loyet KM, Barry VA, Kowalchyk JA (1997) The role of PtdIns $(4,5) \mathrm{P}_{2}$ in exocytotic membrane fusion. Biochem Soc Trans 25:1137-1141.

Nagy G, Matti U, Nehring RB, Binz T, Rettig J, Neher E, Sorensen JB (2002) Protein kinase C-dependent phosphorylation of synaptosome-associated protein of $25 \mathrm{kDa}$ at Ser187 potentiates vesicle recruitment. J Neurosci 22:9278-9286.

Nagy G, Reim K, Matti U, Brose N, Binz T, Rettig J, Neher E, Sorensen JB (2004) Regulation of releasable vesicle pool sizes by protein kinase A-dependent phosphorylation of SNAP-25. Neuron 41:417-429.

Okamoto M, Sudhof TC (1997) Mints, Munc18-interacting proteins in synaptic vesicle exocytosis. J Biol Chem 272:31459-31464.

Olsen HL, Hoy M, Zhang W, Bertorello AM, Bokvist K, Capito K, Efanov AM, Meister B, Thams P, Yang SN, Rorsman P, Berggren PO, Gromada (2003) Phosphatidylinositol 4-kinase serves as a metabolic sensor and regulates priming of secretory granules in pancreatic beta cells. Proc Nat Acad Sci USA 100:5187-5192.

Rettig J, Neher E (2002) Emerging roles of presynaptic proteins in calcium triggered exocytosis. Science 298:781-785.

Rizzoli SO, Betz WJ (2002) Effects of 2-(4-morpholinyl)-8-phenyl-4H-1benzopyran-4-one on synaptic vesicle cycling at the frog neuromuscular junction. J Neurosci 22:10680-10689.

Rohde G, Wenzel D, Haucke V (2002) A phosphatidylinositol (4,5)bisphosphate binding site within $\mu 2$-adaptin regulates clathrin-mediated endocytosis. J Cell Biol 158:209-214.

Schiavo G, Gu QM, Prestwich GD, Sollner TH, Rothman JE (1996) Calcium-dependent switching of the specificity of phosphoinositide binding to synaptotagmin. Proc Natl Acad Sci USA 93:13327-13332.

Sørensen JB, Fernandez-Chacon R, Sudhof TC, Neher E (2003) Examining synaptotagmin 1 function in dense core vesicle exocytosis under direct control of $\mathrm{Ca}^{2+}$. J Gen Physiol 122:265-276.

Sorensen SD, Linseman DA, McEwen EL, Heacock AM, Fisher SK (1998) A role for a wortmannin-sensitive phosphatidylinositol-4-kinase in the endocytosis of muscarinic cholinergic receptors. Mol Pharmacol 53:827-836.

Stauffer TP, Ahn S, Meyer T (1998) Receptor-induced transient reduction in plasma membrane PtdIns(4,5)P2 concentration monitored in living cells. Curr Biol 8:343-346.

Tall EG, Spector I, Pentyala SN, Bitter I, Rebecchi MJ (2000) Dynamics of phosphatidylinositol 4,5-bisphosphate in actin-rich structures. Curr Biol 10:743-746

van Rheenen J, Jalink K (2002) Agonist-induced PIP 2 hydrolysis inhibits cortical actin dynamics: regulation at a global but not at a micrometer scale. Mol Biol Cell 13:3257-3267.

Várnai P, Balla T (1998) Visualization of phosphoinositides that bind pleckstrin homology domains: calcium- and agonist-induced dynamic changes and relationship to myo- $[3 \mathrm{H}]$ inositol-labeled phosphoinositide pools J Cell Biol 143:501-510.

Várnai P, Lin X, Lee SB, Tuymetova G, Bondeva T, Spät A, Rhee SG, Hajnóczky G, Balla T (2002) Inositol lipid binding and membrane localization of isolated pleckstrin homology $(\mathrm{PH})$ domains. Studies on the $\mathrm{PH}$ domains of phospholipase C $\delta_{1}$ and p130. J Biol Chem 277:27412-27422.

Vlahos CJ, Matter WF, Hui KY, Brown RF (1994) A specific inhibitor of phosphatidylinositol 3-kinase, 2-(4-morpholinyl)-8-phenyl-4H-1benzopyran-4-one (LY294002). J Biol Chem 269:5241-5248.

Voets T (2000) Dissection of three calcium-dependent steps leading to secretion in chromaffin cells from mouse adrenal slices. Neuron 28:537-545.

Voets T, Moser T, Lund PE, Chow RH, Geppert M, Sudhof TC, Neher E (2001) Intracellular calcium dependence of large dense-core vesicle exocytosis in the absence of synaptotagmin I. Proc Natl Acad Sci USA 98:11680-11685

Wenk MR, Pellegrini L, Klenchin VA, Di Paolo G, Chang S, Daniell L, Arioka M, Martin T, De Camilli P (2001) PIP kinase Igamma is the major $\mathrm{PI}(4,5) \mathrm{P}(2)$ synthesizing enzyme at the synapse. Neuron 32:79-88.

Xu T, Binz T, Niemann H, Neher E (1998) Multiple kinetic components of exocytosis distinguished by neurotoxin sensitivity. Nat Neurosci 1:192-200. 